\title{
Habitat relationships of the pyrenean gray partridge
}

\author{
FRANÇOISE LESCOURRET AND MICHEL GENARD
}

\begin{abstract}
Authors at the time of the study were with Office National de la Chasse, BP34, F-31800 Saint-Gaudens; and GEREA, Université de Bordeaux I, UER Biologie, Avenue des Facultés, F-33405 Talence Cédex. Authors are currently with INRA, Centre de Clermont-Ferrand-Theix, Laboratoire d'Ecopathologie, F-63122 Saint-GenèsChampanelle; and INRA, Centre d'Avignon, Station d'Agronomie, Domaine Saint Paul, F-84143 Montfavet Cédex.
\end{abstract}

\begin{abstract}
Summer habitat relationships of the pyrenean gray partridge (Perdix perdix hispaniensts) were studied in the northern Pyrenees Mountains (France). Six available habitat types were defined, and those selected or avoided were identified. The only habitat type significantly $(p<0.05)$ selected was at intermediate altitudes, on fairly steep south-exposed slopes, with a moderate cover of woody plants. Two habitat types were significantly avoided. One occurred at low altitudes on mowed plateaus colonized by low woody plants, and the other was at high altitudes on slopes free of low woody plants. We suggest applications of the work in a model that should lead to valid habitat recommendations for restoring partridge populations.
\end{abstract}

Key Words: Pyrenean gray partridge (Perdix perdix hispaniensis), French Pyrenees, habitat, multivariate analysis

The gray partridge has disappeared from most European mountains. Nevertheless, populations of Perdix perdix hispaniensis still exist in the Pyrenees and Cantabrics (southern France and Spain) (De Juana 1980, Lescourret and Catusse 1987, Lescourret and Ellison 1987). These populations appear to be declining because of deterioration of their habitats (Lescourret 1988). Consequently, definition of habitat management policies for restoring the gray partridge is critical. This definition can only be based on sound knowledge of habitat relationships. Past studies of gray partridge habitat (Lescourret 1988, Novoa and Gonzalez 1988) have not treated vegetation structure and composition. Further, they used an univariate approach, which cannot give the synthetic picture of habitat relationships provided by multivariate analyses (Shugart 1981, Carnes and Slade 1982). Some multivariate studies have compared occupied and unoccupied sites using discriminant analysis (Johnson 1981). Unoccupied sites are frequently not known, and habitat studies are often limited to comparison between occupied sites and sites randomly chosen in the study area. Using discriminant analysis is then misleading (James et al. 1984). A better approach is to describe the environment using multivariate analysis of the random points. This provides habitat description over a reduced space, on which occupied sites can be positioned (Rotenberry and Wiens 1981).

We used such an approach to investigate habitat relationships of pyrenean gray partridge. The objectives were to (1) define summer habitat types available to gray partridge in the French Pyrenees, and (2) identify habitat types selected and those avoided.

\section{Study Area}

The study area included 1,745 ha, representing a large range of

\footnotetext{
The study was supported by the Office National de la Chasse and the French Environment Ministry (Research convention (EGPN-SRETIE/ONC $\mathrm{N}^{\circ}$ 87232), thanks to an agreement with the Fédération Départementale des Chasseurs des Hautes Pyrenees. We thank C.E. Braun and L. Ellison for improving the English.

Manuscript accepted 17 Jan. 1993.
}

habitat conditions (elevation, orientation, topography, vegetation) in the northern Pyrenees, in the valley of the Gave de Gavarnie ( $44^{\circ}$ $\mathrm{N}$. Lat., $0^{\circ}$ Long.). The climate is oceanic montane and the landscape has been managed since 5000 B.C. to favor grazing (Cantegrel 1983, Jalut 1984).

The open montane zone (900-1,800 m) is Brachypodium pinnatum or Festuca rubra grasslands, and Vaccinium myrtillus or Calluna vulgaris heaths. The open subalpine zone $(1,500-2,400 \mathrm{~m})$ is Festuca eskia or Nardus stricta grasslands and Rhododendron ferrugineum, Vaccinium myrtillus, Calluna vulgaris or Juniperus nana heaths. The alpine zone $(>2,200 \mathrm{~m})$ is dominated by grasslands and boulders (Gruber 1978, Dupias 1985).

\section{Methods}

\section{Sampling Design}

The 1,745-ha study area was sampled by walking grid lines based on rectangles $250 \times 500 \mathrm{~m}$. The grid lines, totaling $48 \mathrm{~km}$, were walked twice, in August and September 1987, by 2 observers traveling simultaneously along parallel strips. Observers looked for birds and signs of their presence (feathers, tracks, and droppings). Droppings constituted $74 \%$ of the signs observed. We verified that "field life" of droppings was short, by examining the gradual change of several samples of fresh droppings. All 155 droppings examined totally disintegrated within $\mathbf{4 0}$ days.

Habitat was described within a 50 -m radius of each bird observation or sign of presence and at each grid intersection. Descriptors included elevation, topography, exposure, slope, dominant plant species, stone cover ( $<50 \mathrm{~cm}$ diameter), and boulder cover $>50$ $\mathrm{cm}$ diameter). Cover of grasses, forbs, and woody plants was measured in 3 vegetation layers $(0-10 \mathrm{~cm}, 11-25 \mathrm{~cm}, 26-50 \mathrm{~cm})$. Percent cover was estimated by comparison with reference drawings representing imaginary covers of $1,5,10 \%$, etc. (Prodon and Lebreton 1981). Habitat descriptions were made at 62 sites where birds or their signs were recorded and at 202 grid intersections.

\section{Statistical Analysis}

Prior to definition of available habitat types, we identified vegetation types by performing a correspondence analysis (C.A. (Benzécri 1973) on the dominant plant species recorded at the 202 grid sites. We used an eigenvector approach for the correspondence analysis, i.e., a special Principal Component Analysis for qualitative variables. These 202 sites were described by their scores on the highest ranking components clustered by an ascending hierarchical clustering using Ward's minimum-variance method (Ward 1963). Each cluster corresponded to a vegetation type.

Quantitative variables were transformed into categorical variables by creating classes (for example, $<1,771$, 1,771-1,915, $1,916-2,120,>2,120 \mathrm{~m}$ for elevation). Qualitative variables were also divided into categories ( $\mathrm{S}, \mathrm{N}, \mathrm{SW}$, etc. for exposure). Each site was assigned the number 1 for the class or category of a variable describing it and 0 for the other classes or categories (a site 1,900 
m-high was assigned a 1 in the $1,771-1,915 \mathrm{~m}$ class and a 0 in the other elevation classes). This procedure preserved nonlinear relationships between variables (Johnson 1981) and allowed qualitative and quantitative variables to be processed together. The 16 descriptors were represented by 62 categorical variables (Table 1).

Table 1. Categories of habitat variables (identified by numbers, adjectives, or letters).

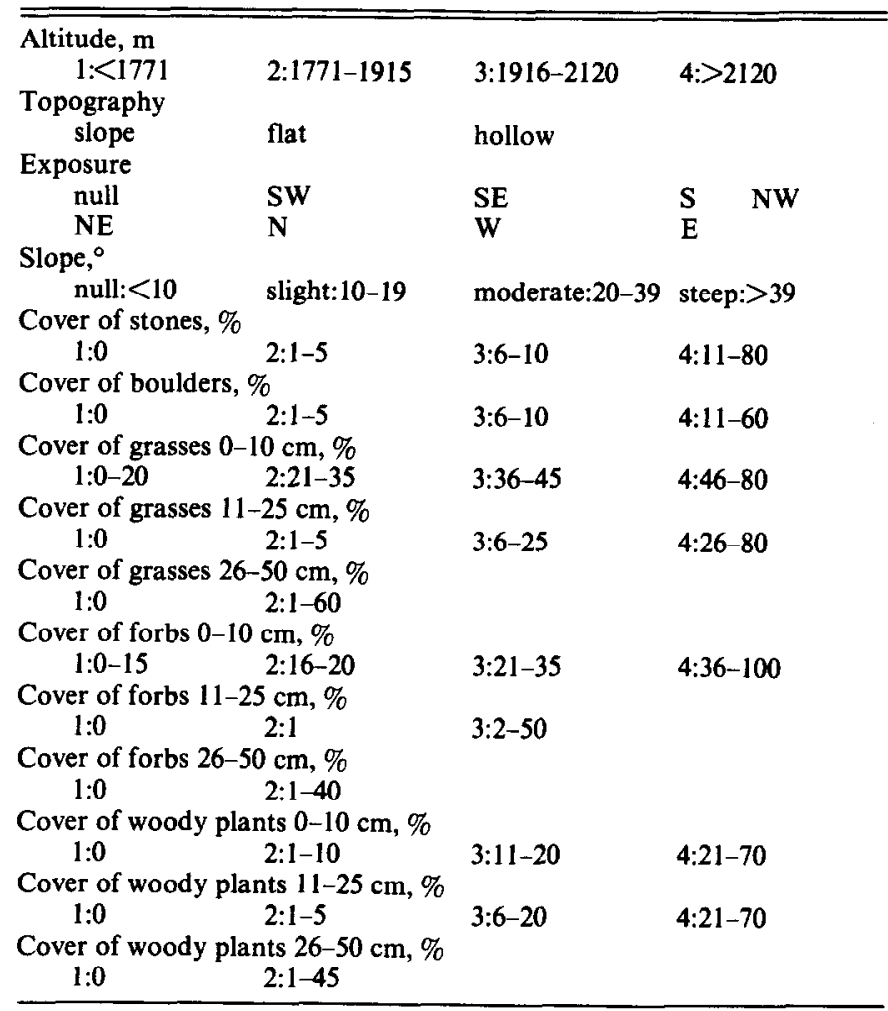

To identify the main habitat features in the study area, a multiple correspondence analysis was performed on the data from 202 grid sites by 62 categorial variables. The eigenvector approach was used. The search for contributive raw variables (i.e., not divided into classes) was helped by examining the correlation ratio between variable and factor (Pialot et al. 1984), which was

$$
\mu^{2}\left(F_{\alpha} q\right)=v \lambda_{\alpha} \Sigma_{j \alpha} J(q) C T R_{\alpha}(j)
$$

with $\mathrm{F}_{\alpha}$ being factor $\alpha \lambda_{\alpha}$ its variance, $\mathrm{q}$ a variable, $v$ the number of variables, $J(q)$ the set of categories of $q$, j one of them, CTR $\alpha$ (j) the contribution of $j$ to $F_{\alpha}$, i.e., the part of $F_{\alpha}$ 's variance explained by $j$. It is easy to demonstrate from the formula that the mean of $\mu^{2}\left(\mathrm{~F}_{\alpha} \mathrm{q}\right)$ among the variables is $\lambda_{\alpha}$. Consequently, a variable was contributive when have $\mu^{2}\left(\mathrm{~F}_{\alpha} q\right)>\lambda_{\alpha}$. Grid sites described by their scores on the highest corresponding analysis ranking components were clustered by an ascending hierarchical clustering, allowing us to define available habitat types.

Sites used by partridges were assigned to vegetation type and then to habitat type, using a proximity rule. First, scores of the use sites on the corresponding analysis components used for clustering were calculated using the eigenvectors matrix. Second, the Mahalanobis distance from each site to each center of the clusters corresponding to the types was calculated. Each site was then assigned to the cluster of the closest center.

Distribution of 202 grid and 62 use sites among the habitat types was compared using a chi-square goodness-of-fit test. In the case of rejecting the null hypothesis (similar distribution), simultaneous confidence intervals were calculated (Neu et al. 1974, Marcum and Loftsgaarden 1980, Byers and Steinhorst 1984).
Results

\section{Vegetation Types}

Five vegetation types were defined (Table 2). Type A (montane zone vegetation) was characterized by plants common on mowed grasslands and on productive pastures. Its species richness was high (25) and it included numerous forbs. Type B (also montane zone vegetation) was generally found on southern or western slopes. Types $\mathrm{C}$ and $\mathrm{D}$ were dominated by subalpine vegetation, with $C$ on northern slopes and $D$ on southern slopes. Type $E$ included rocky biotopes and represented the high subalpine and low alpine zones.

Table 2. Frequency of occurrence (\%) of plant species in 5 vegetation types.

\begin{tabular}{|c|c|c|c|c|c|}
\hline Categories/species & $\begin{array}{r}\text { Mont } \\
\text { A }\end{array}$ & $\mathrm{B}$ & $\mathrm{C}$ & $\mathrm{D}$ & $\begin{array}{c}\text { Alpine } \\
\text { E }\end{array}$ \\
\hline$\simeq$ sites & 33 & 61 & 64 & 23 & 21 \\
\hline Richness" & 25 & 20 & 21 & 15 & 16 \\
\hline Achilleum millefolium & 24 & 0 & 0 & 0 & 0 \\
\hline Agrostis sp. & 20 & 0 & 0 & 0 & 0 \\
\hline Potentilla sp. & 29 & 3 & 0 & 0 & 0 \\
\hline Trifolium pratense & 20 & 3 & 1 & 0 & 9 \\
\hline Juniperus nana & 39 & 15 & 14 & 9 & 5 \\
\hline Galium verum & 59 & 24 & 3 & 4 & 14 \\
\hline Festuca rubra & 67 & 30 & 0 & 0 & 0 \\
\hline Nardus stricta & 59 & 21 & 17 & 4 & 38 \\
\hline Brachypodium pinnatum & 5 & 50 & 0 & 0 & 0 \\
\hline Pteridium aquilinum & 0 & 15 & 0 & 0 & 0 \\
\hline Festuca scoparia & 0 & 3 & 0 & 0 & 0 \\
\hline Helianthemum nummularium & 29 & 72 & 1 & 9 & 5 \\
\hline Calluna vulgaris & 23 & 48 & 8 & 17 & 0 \\
\hline Carex sp. & 8 & 21 & 3 & 0 & 14 \\
\hline Potentilla tormentilla & 21 & 24 & 22 & 0 & 0 \\
\hline Hieratium pilosella & 8 & 9 & 6 & 4 & 5 \\
\hline Plantago alpina & 2 & 0 & 5 & 0 & 0 \\
\hline Vaccinium myrtillus & 18 & 24 & 58 & 26 & 5 \\
\hline Rhododendron ferrugineum & 13 & 0 & 48 & 9 & 5 \\
\hline Vaccinium uliginosum & 6 & 0 & 28 & 0 & 0 \\
\hline Trifolium alpinum & 23 & 0 & 48 & 13 & 24 \\
\hline Festuca eskia & 21 & 3 & 87 & 83 & 43 \\
\hline Cerastium fontanum & 0 & 0 & 1 & 0 & 0 \\
\hline Thymus serpyllum & 15 & 48 & 20 & 74 & 43 \\
\hline Veronica fruticans & 0 & 6 & 1 & 52 & 0 \\
\hline Senecio adonidifolius & 0 & 0 & 0 & 48 & 0 \\
\hline Alchemilla sp. & 6 & 6 & 11 & 9 & 19 \\
\hline Mosses & 2 & 3 & 5 & 0 & 28 \\
\hline Lotus corniculatus & 6 & 0 & 0 & 4 & 43 \\
\hline Plantago atrata & 2 & 0 & 1 & 0 & 62 \\
\hline
\end{tabular}

Richness = number of species or categories per type.

\section{Available Habitat Types}

The main habitat features in the study area were represented by the first 4 factors F1-F4 of the multiple correspondence analysis (Figs. 1, 2), whose eigenvalues were $0.28,0.21,0.17$, and 0.15 .

The most important feature was elevation, which had the greatest correlation ratio with factor F1. Cover of stones increased and that of grasses $>25 \mathrm{~cm}$ decreased with altitude. Another important feature was a gradient of colonization by low woody plants, noticeable especially on $F 2$, but also on $F 1$, through strong correlation ratios of covers of woody plants $<10 \mathrm{~cm}$ and $11-25 \mathrm{~cm}$. Plateau stations (flat topography, null slope, and exposure) were separated from the others on the F1 $\times F 2$ plane. The pattern of vegetation types in the $F 1 \times F 2$ plane was parabolic, indicating a relation of plant species composition with elevation and colonization by woody plants (Fig. 1).

An exposure gradient from cold $(\mathrm{N})$ to warm (S) exposures was expressed on F3. Cover of woody plants was related to this gradient, being highest in cold situations where rhododendron domi- 
ALTITUDE

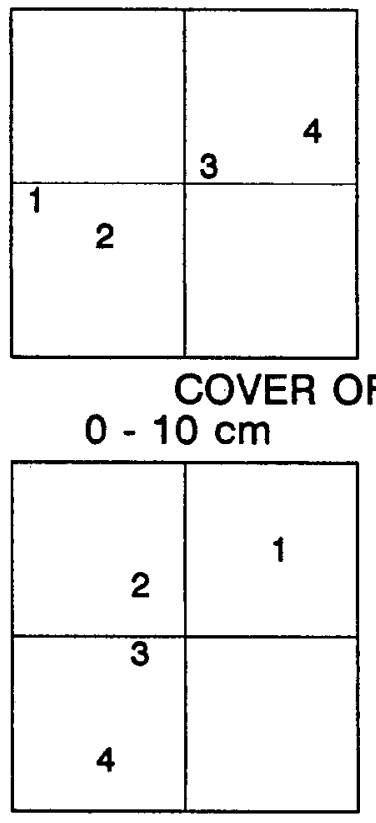

EXPOSURE

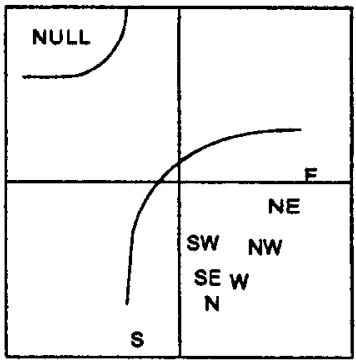

COVER OF STONES

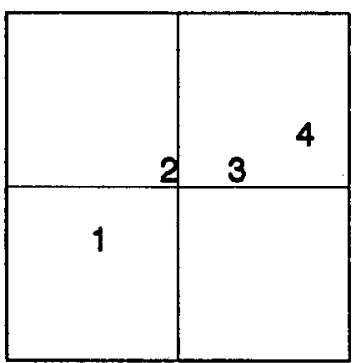

$11.25 \mathrm{~cm}$

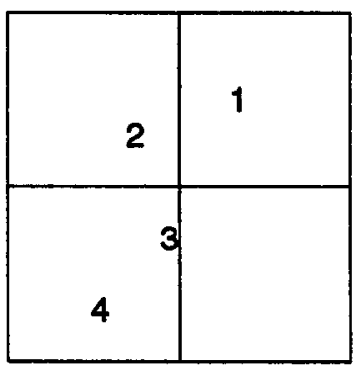

STEEPNESS OF SLOPE

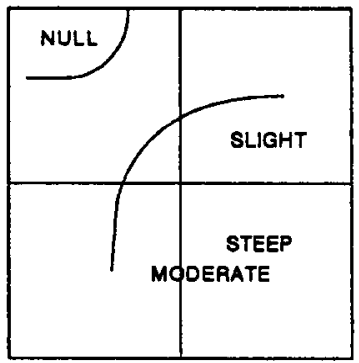

COVER OF GRASSES

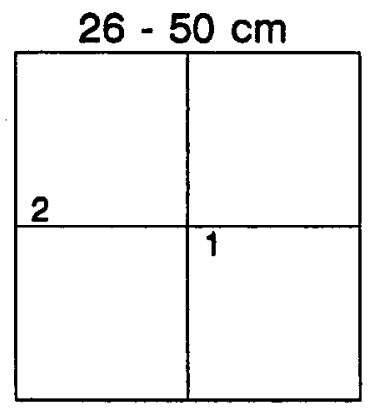

TOPOGRAPHY

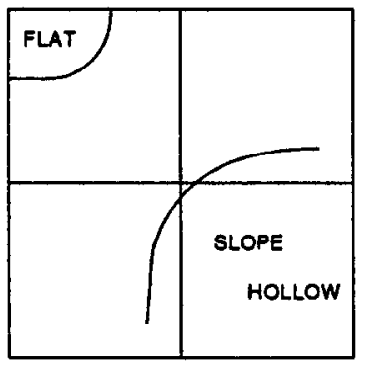

VEGETATION TYPE

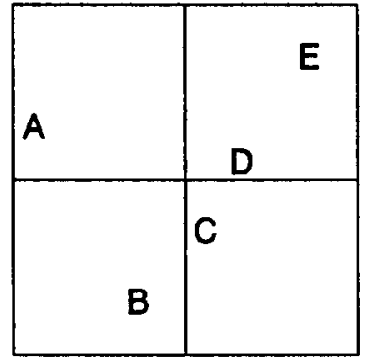

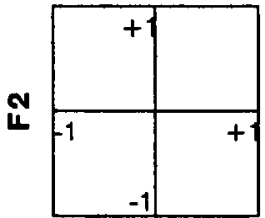

F1

Fig. 1. Distribution of categories of contributive habitat variables in the F1 $\times F 2$ plane of the multiple correspondence analysis. Categories are represented by numbers, letters or adjectives (Table 1).

nated. Factor F4 represented both an increase in cover of low grasses $(\angle 25 \mathrm{~cm})$ and a decrease in cover of boulders and $11-25 \mathrm{~cm}$ forbs. Cover of woody plants $11-25 \mathrm{~cm}$ was also related to $\mathrm{F} 4$. Vegetation types B, C, D seemed to be especially linked to factors 3 and 4 (Fig. 2).

Clustering allowed us to define 6 available habitat types whose main features can be synthesized by projecting the types on the factor planes. Habitat types $1,2,3$, and 6 were separated from each other and from the group of habitat types $4+5$ on the F1 $\times F 2$ plane (Fig. 3). Habitat types, 1, 2+3, 4+5, and 6 were ordered on the elevation gradient, and $2+6,1+4+5$, and 3 on the gradient of colonization by low woody plants. Habitat types 4 and 5 were separated from each other on the exposure gradient, with 4 on south slopes and 5 on north slopes (Fig. 4, Table 3).

\section{Selected and Avoided Habitat Types}

Use sites were associated with habitat types 3,4 , and 5 , i.e., with intermediate altitudes, medium to high cover of woody plants, vegetation types $B, C$, and $D$, and fairly steep slopes (Figs. 3, 1). None of the variables correlated with F3 (exposure) or F4 (boulders and forbs) seemed to be critical for partridges, as use sites were almost randomly distributed on the F3 $\times$ F4 plane (Fig. 4).

Only habitat type 4 was significantly $(p<0.05)$ selected (Fig. 5). It was at intermediate altitudes, on south slopes, with vegetation types $B$ and D, and a moderate cover of woody plants. Habitat types 1 and 6 were significantly $(p<0.05)$ avoided (Fig. 5). Habitat type 1 was at low altitudes, on plateaus well colonized by low woody plants, and was characterized by vegetation type A. Habitat type 6 was at high altitudes on slopes free of low woody plants, and was characterized by vegetation types $C$ and $E$.

\section{Discussion}

Elevation, exposure, and slope features of the habitat types selected by gray partridge in this study resembled those reported in earlier investigations (Lescourret 1988, Novoa and Gonzalez 1988). Gray partridges preferred slopes to flat ground, apparently to facilitate escape flights from predators or humans. They also selected southern exposures (habitat type 4), where early snow melt and warm temperatures may favor nesting and fledging success. Habitat type 6 may have been avoided because of more inclement weather conditions that normally prevail at higher altitudes.

Invasion of the study area by low woody plants was indicative of a decrease in grazing pressure in recent years. Although declines of populations following abandonment of grazing have been documented in the literature for different galliforms (ONC 1986, Magnani 1988, Novoa and Gonzalez 1988, Génard and Lescourret 1990), we found no evidence that partridge numbers decreased following invasion of low woody plants in our study area. On the contrary, signs of partridge were more frequent when cover of 


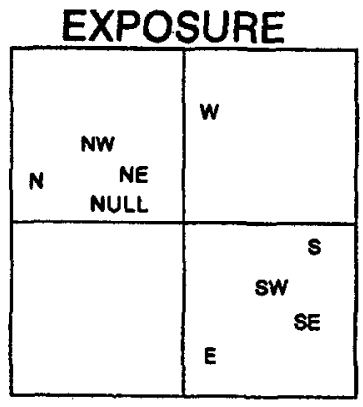

COVER OF WOODY

PLANTS

$26.50 \mathrm{~cm}$

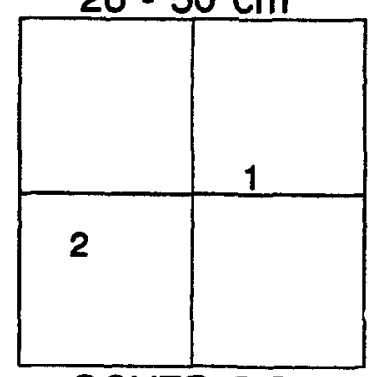

COVER OF

BOULDERS

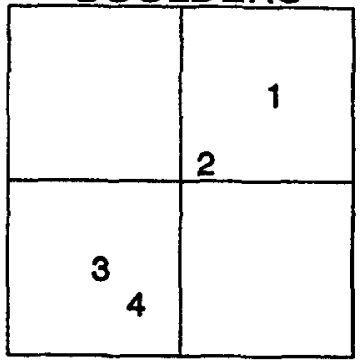

COVER OF. WOODY PLANTS
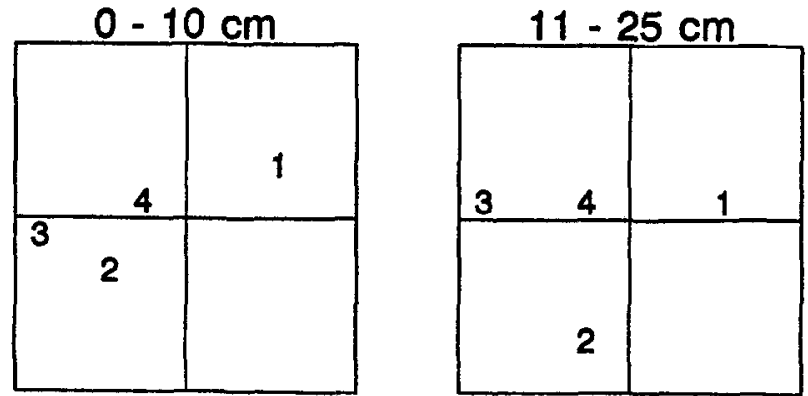

\section{COVER OF GRASSES}
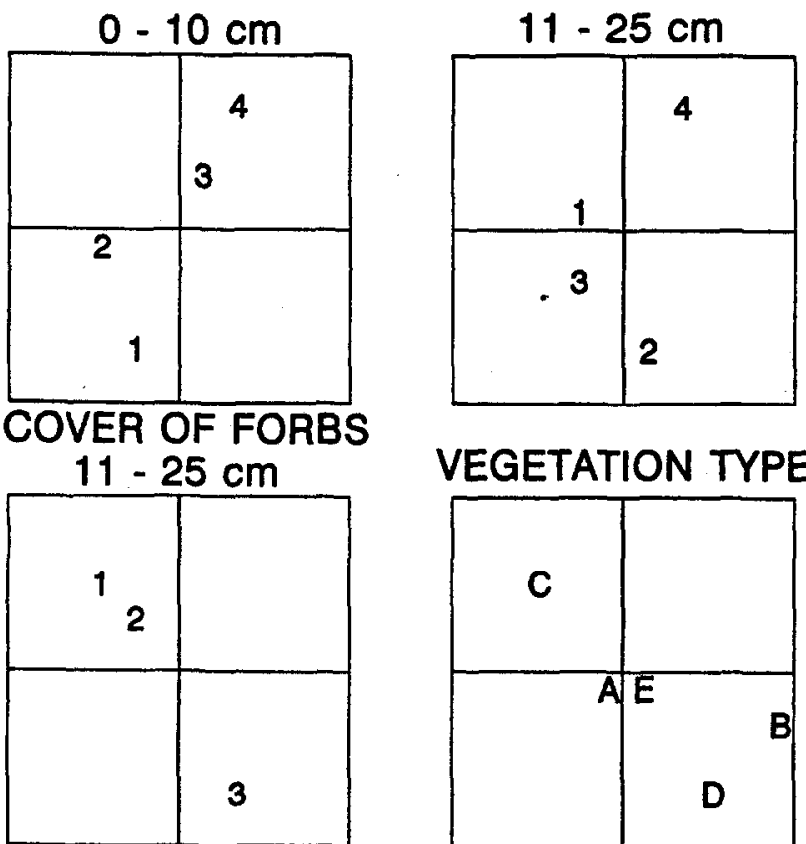

VEGETATION TYPE
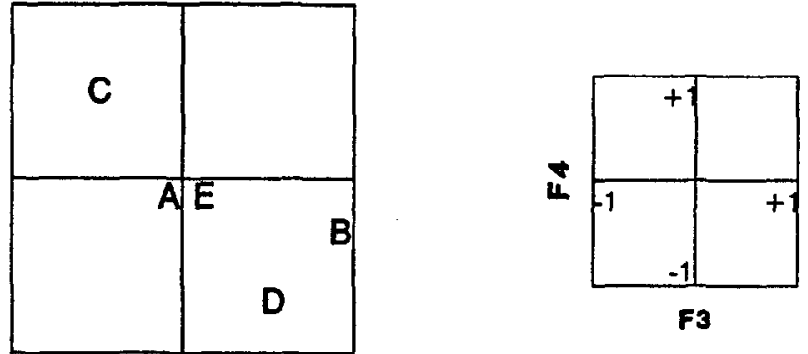

Fig. 2. Distribution of categories of contributive habitat variables in the F3 $\times$ F4 plane of the multiple correspondence analysis. Categories are represented by numbers, letters, or adjectives (Table 1).

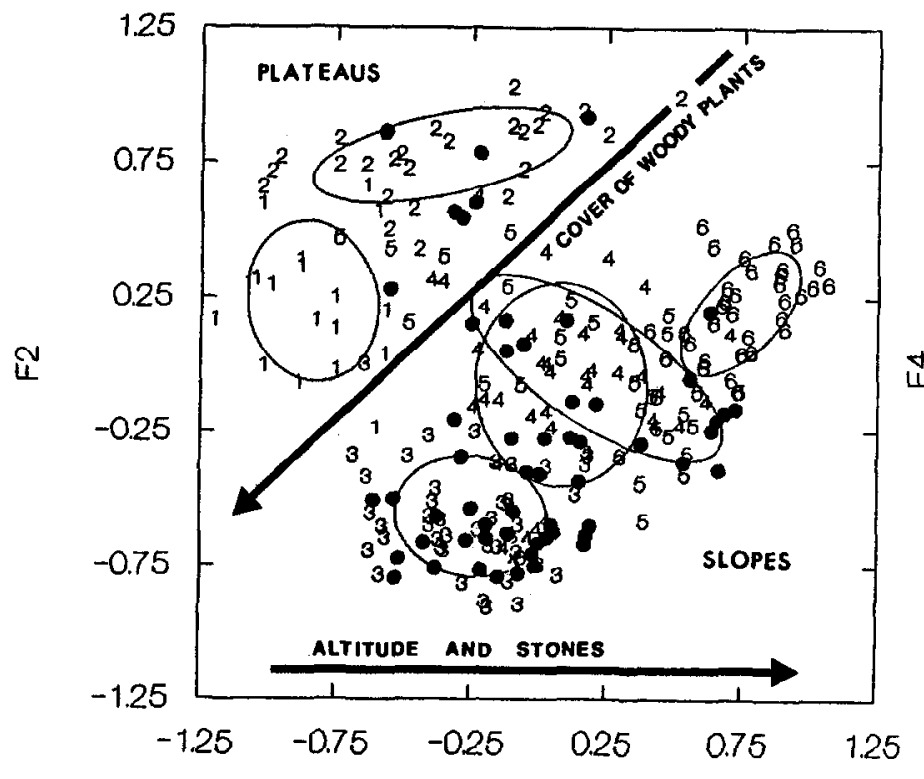

F1

Fig. 3. Projection on the F1 $\times$ F2 plane of the multiple correspondence analysis of (i) 6 habitat types represented by contents (grid sites) and dispersion ellipses ( $\sqrt{x} \pm$ SD), (ii) partridge use sites (black spots).

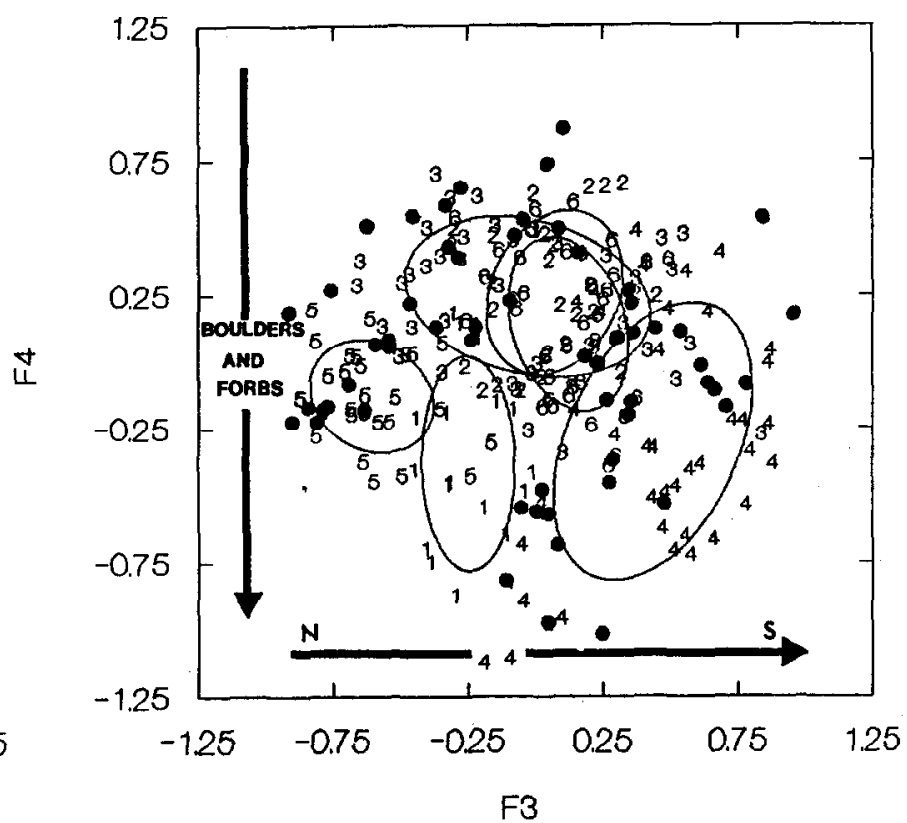

Fig. 4. Projection on the F3 $\times$ F4 plane of the multiple correspondence analysis of (i) 6 habitat types represented by contents (grid sites) and dispersion ellipses ( $\sqrt{x} \pm$ SD), (ii) partridge use sites (black spots).

JOURNAL OF RANGE MANAGEMENT 46(4), July 1993 
Table 3. Frequency of occurrence (\%) of habitat categorical variables by habitat type.

\begin{tabular}{|c|c|c|c|c|c|c|}
\hline Variables & $\begin{array}{r}\text { Montane - } \\
1\end{array}$ & $\cdots$ & 3 & 4 & 5 & $\rightarrow_{6}$ Alpine \\
\hline $\begin{array}{l}\text { حites } \\
\text { Altitude, } \mathrm{m}\end{array}$ & 18 & 26 & 49 & 42 & 30 & 37 \\
\hline $\begin{array}{l}\text { Topography } \\
\text { slope } \\
\text { flat } \\
\text { hollow }\end{array}$ & $\begin{array}{r}22 \\
78 \\
0\end{array}$ & $\begin{array}{l}0 \\
1 \\
0\end{array}$ & $\begin{array}{r}94 \\
2 \\
4\end{array}$ & $\begin{array}{r}96 \\
2 \\
2\end{array}$ & $\begin{array}{l}67 \\
23 \\
10\end{array}$ & $\begin{array}{r}89 \\
0 \\
11\end{array}$ \\
\hline $\begin{array}{c}\text { Exposure } \\
\text { null } \\
\text { SW } \\
\text { SE } \\
\text { S } \\
\text { NW } \\
\text { NE } \\
\text { N } \\
\text { W } \\
\text { E }\end{array}$ & $\begin{array}{r}69 \\
0 \\
0 \\
0 \\
8 \\
8 \\
15 \\
0 \\
0\end{array}$ & $\begin{array}{r}100 \\
0 \\
0 \\
0 \\
0 \\
0 \\
0 \\
0 \\
0\end{array}$ & $\begin{array}{r}2 \\
10 \\
6 \\
25 \\
21 \\
12 \\
18 \\
6 \\
0\end{array}$ & $\begin{array}{r}2 \\
26 \\
24 \\
19 \\
0 \\
7 \\
7 \\
3 \\
12\end{array}$ & $\begin{array}{r}23 \\
0 \\
0 \\
0 \\
14 \\
30 \\
30 \\
0 \\
3\end{array}$ & $\begin{array}{r}0 \\
15 \\
4 \\
9 \\
9 \\
37 \\
0 \\
13 \\
13\end{array}$ \\
\hline $\begin{array}{l}\text { Slope, }{ }^{\circ} \\
\text { null: }<10 \\
\text { slight: } 10-19 \\
\text { moderate: } 20-39 \\
\text { steep: }>39\end{array}$ & $\begin{array}{r}77 \\
11 \\
6 \\
6\end{array}$ & $\begin{array}{r}96 \\
4 \\
0 \\
0\end{array}$ & $\begin{array}{r}2 \\
14 \\
49 \\
35\end{array}$ & $\begin{array}{r}2 \\
12 \\
57 \\
29\end{array}$ & $\begin{array}{l}27 \\
23 \\
37 \\
13\end{array}$ & $\begin{array}{r}0 \\
30 \\
35 \\
35\end{array}$ \\
\hline 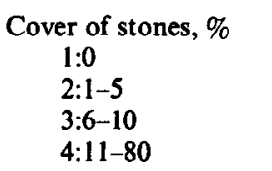 & $\begin{array}{r}67 \\
11 \\
17 \\
5\end{array}$ & $\begin{array}{r}61 \\
23 \\
12 \\
4\end{array}$ & $\begin{array}{r}84 \\
16 \\
0 \\
0\end{array}$ & $\begin{array}{l}24 \\
22 \\
27 \\
27\end{array}$ & $\begin{array}{r}7 \\
36 \\
27 \\
30\end{array}$ & $\begin{array}{l}13 \\
11 \\
14 \\
62\end{array}$ \\
\hline $\begin{array}{l}\text { Cover of boulders, } \% \\
\quad 1: 0 \\
2: 1-5 \\
3: 6-10 \\
4: 11-60\end{array}$ & $\begin{array}{l}17 \\
33 \\
28 \\
22\end{array}$ & $\begin{array}{r}35 \\
35 \\
7 \\
23\end{array}$ & $\begin{array}{r}72 \\
18 \\
8 \\
2\end{array}$ & $\begin{array}{l}29 \\
29 \\
16 \\
26\end{array}$ & $\begin{array}{r}3 \\
10 \\
40 \\
47\end{array}$ & $\begin{array}{r}32 \\
5 \\
20 \\
43\end{array}$ \\
\hline $\begin{array}{l}\text { Cover of grasses } 26-50 \\
\quad 1: 0 \\
2: 1-60\end{array}$ & $\begin{array}{l}28 \\
72\end{array}$ & $\begin{array}{l}65 \\
35\end{array}$ & $\begin{array}{l}65 \\
35\end{array}$ & $\begin{array}{l}62 \\
38\end{array}$ & $\begin{array}{l}90 \\
10\end{array}$ & $\begin{array}{r}97 \\
3\end{array}$ \\
\hline $\begin{array}{l}\text { Cover of forbs } 0-10 \mathrm{cr} \\
1: 0-15 \\
2: 16-20 \\
3: 21-35 \\
4: 36-100\end{array}$ & $\begin{array}{l}17 \\
17 \\
22 \\
44\end{array}$ & $\begin{array}{l}12 \\
19 \\
27 \\
42\end{array}$ & $\begin{array}{r}28 \\
33 \\
37 \\
2\end{array}$ & $\begin{array}{l}26 \\
21 \\
10 \\
43\end{array}$ & $\begin{array}{l}40 \\
17 \\
33 \\
10\end{array}$ & $\begin{array}{r}41 \\
32 \\
19 \\
8\end{array}$ \\
\hline $\begin{array}{l}\text { Cover of forbs 11-25 } \\
\quad 1: 0 \\
2: 1 \\
3: 2-50\end{array}$ & $\begin{array}{r}6 \\
33 \\
61\end{array}$ & $\begin{array}{r}85 \\
11 \\
4\end{array}$ & $\begin{array}{r}82 \\
14 \\
4\end{array}$ & $\begin{array}{r}31 \\
7 \\
62\end{array}$ & $\begin{array}{r}90 \\
7 \\
3\end{array}$ & $\begin{array}{r}97 \\
0 \\
3\end{array}$ \\
\hline $\begin{array}{l}\text { Cover of forbs } 26-50 \mathrm{c} \\
\quad 1: 0 \\
2: 1-40\end{array}$ & $\begin{array}{l}39 \\
61\end{array}$ & $\begin{array}{l}89 \\
11\end{array}$ & $\begin{array}{l}67 \\
33\end{array}$ & $\begin{array}{l}69 \\
31\end{array}$ & $\begin{array}{r}100 \\
0\end{array}$ & $\begin{array}{r}100 \\
0\end{array}$ \\
\hline $\begin{array}{l}\text { Cover of woody plants } \\
\begin{array}{l}1: 0 \\
2: 1-10 \\
3: 11-20 \\
4: 21-70\end{array}\end{array}$ & $\begin{array}{r}0 \\
44 \\
28 \\
28\end{array}$ & $\begin{array}{r}77 \\
19 \\
4 \\
0\end{array}$ & $\begin{array}{r}0 \\
12 \\
21 \\
67\end{array}$ & $\begin{array}{r}57 \\
22 \\
7 \\
14\end{array}$ & $\begin{array}{r}0 \\
33 \\
44 \\
23\end{array}$ & $\begin{array}{r}92 \\
5 \\
3 \\
0\end{array}$ \\
\hline
\end{tabular}


Table 3. Continued.

\begin{tabular}{|c|c|c|c|c|c|c|}
\hline Variables & Montane - & $\frac{-}{2}$ & 3 & -- & 5 & $-\frac{1}{6}$ Alpine \\
\hline \multicolumn{7}{|c|}{ Cover of woody plants $11-25 \mathrm{~cm}, \%$} \\
\hline $1: 0$ & $\mathbf{0}$ & 85 & 0 & 63 & 0 & 95 \\
\hline $2: 1-5$ & 39 & 11 & 4 & 14 & 23 & 0 \\
\hline $3: 6-20$ & 33 & 4 & 41 & 9 & 54 & 5 \\
\hline $4: 21-70$ & 28 & 0 & 55 & 14 & 23 & 0 \\
\hline \multicolumn{7}{|c|}{ Cover of woody plants $26-50 \mathrm{~cm}, \%$} \\
\hline $1: 0$ & 6 & 96 & 33 & 60 & 17 & 97 \\
\hline $2: 1-45$ & 94 & 4 & 67 & 40 & 83 & 3 \\
\hline \multicolumn{7}{|c|}{ Vegetation type } \\
\hline A & 100 & 62 & 26 & 19 & 18 & 0 \\
\hline B & 0 & 0 & 31 & 41 & 0 & 3 \\
\hline $\mathrm{C}$ & 0 & 15 & 43 & 7 & 64 & 46 \\
\hline D & 0 & 8 & 0 & 31 & 4 & 19 \\
\hline E & 0 & 15 & 0 & 2 & 14 & 32 \\
\hline
\end{tabular}

woody plants increased (low values of factor F2). We conclude that extent of colonization of low woody plants was not yet important enough to cause a decline in partridge numbers.

The diet of the pyrenean gray partridge is composed of green plant material, bulbs, insects ( $30 \%$ of which are Orthoptera), seeds, and dry fruits (Novoa in Bernard-Laurent 1986). These foods are abundant at low and intermediate altitudes, but they are scarce at high altitudes, which may be another reason partridges avoided habitat type 6. The rock ptarmigan (Lagopus mutus) is the only galliform occupying high altitude areas likely to compete with the gray partridge. Rock ptarmigan prefer high subalpine and alpine zones that tend to be relatively cold and rocky and less steep than areas usually occupied by partridges (Novoa and Gonzalez 1988). These features are similar to those of habitat type 6, which suggests that a competitive exclusion may also influence partridge distribution. Finally, open grassy areas offer little cover to protection against predators, which may also contribute to low use of habitat types 2 and 6.
Our results can be used to predict the presence or absence of the Pyrenean gray partridge. The methodological design of our work can be transcribed in a stepwise model allowing assignment of any new site to a vegetation type and to a habitat type, on the basis of a few habitat measurements, by means of the eigenvector matrices and proximity rules we calculated. Presence or absence of partridges in the site can be predicted from the suitability of the habitat (preferred or avoided). Such a model can also be used to assess changes in the occurrence of the species induced by changes in the landscape (Génard and Lescourret 1990). The model must be tested in other areas to determine if it is robust enough to be applied generally in the Pyrenees. The tests will require a thorough examination of both its internal validity (stablity of the detected structure), and its external validity (statistical inference).

\section{Literature Cited}

Benzécri, J.P. 1973. L'analyse des données. II. L'analyse des correspondances. Dunod, Paris.

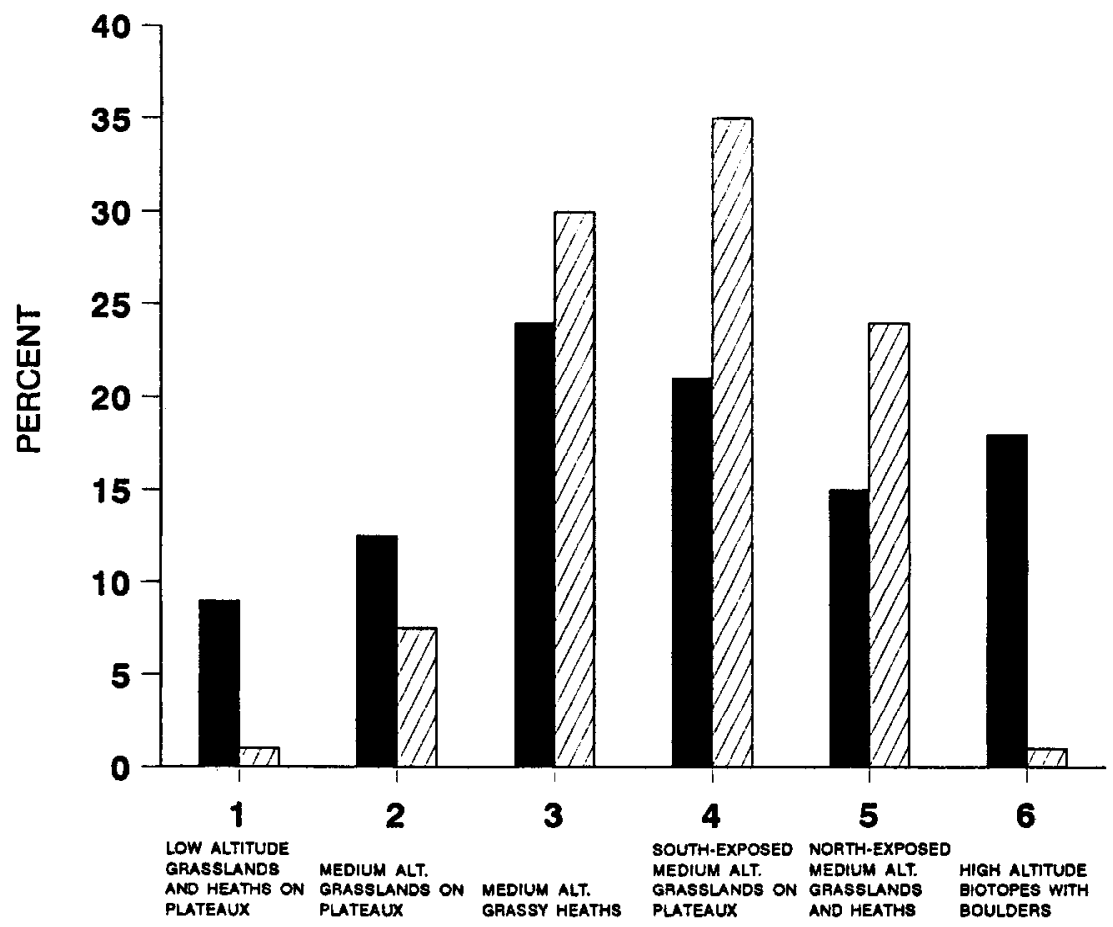

Fig. 5. Frequency of occurrence of grid sites (black) and of partridge use sites (cross-hatched) in 6 habitat types. 
Bernard-Laurent, A. 1986. Régime alimentaire automnal de la Perdrix bartavelle, Alectoris graeca saxatilis, dans les Alpes-Maritimes. Rev. Ecol. (Terre Vie) 41:39-57.

Byers, C.R., and R.K. Steinhorst. 1984. Clarification of a technique for analysis of utilization-availability data. J. Wildl. Manage. 48:1050-1053.

Cantegrel, R. 1983. Le pin à crochets pyrénéen. Biologie, biochimie, sylviculture. Acta Biol. Mont. 2-3:87-330.

Carnes, B.A., and N.A. Slade. 1982. Some comments on niche analysis in canonical space. Ecology 63:888-893.

De Juana, E. 1980. Atlas ornithologico de la Rioja. Instituto de Estudios Riojanes, Spain.

Dupias, G. 1985. Végétation des Pyrénées. Editions du CNRS, Paris.

Génard, M., and F. Lescourret. 1990. Modélisation de la carte de répartition d'une espèce, appliquée au cas des perdrix (Perdix perdix hispaniensis Reich. et. Alectoris rufa L.) dans les Pyrénées Orientales. Gibier Faune Sauvage 7:205-230.

Gruber, M. 1978. La végétation des Pyrénées ariégeoises et catalanes occidentales. State Thesis, University of Aix-Marseille, France.

Jalut, G. 1984. L'action de l'homme sur la forêt montagnarde des Pyrénées ariégeoises et orientales depuis $4000 \mathrm{BP}$ d'après l'analyse pollinique, p. 163-172. In: Actes du 106e colloque du Congrès National des Sociétés Savantes, Perpignan, France.

James, F.C., R.F. Johnston, N.O. Wamer, G.J. Niemi, and W.J. Broecklen. 1984. The Grinnellian niche of the wood thrush. Amer. Nat. 124:17-30.

Johnson, D.H. 1981. The use and misuse of statistics in wildlife habitat studies, p. 11-19. In: D. Capen (ed.), The use of multivariate statistics in studies of wildlife habitat. U.S. Dep. Agr. For. Serv. Gen. Tech. Rep. RM 87.

Lescourret, F. 1988. Eléments de répartition de la perdrix grise (Perdix perdix hispaniensis Reich.) dans les Pyrénées francaises. Gibier Faune Sauvage 5:123-148.

Lescourret, F., and M. Catusse. 1987. Que sait-on aujord hui sur la perdrix grise des Pyrénées (Perdix perdix hispaniensis Reichenow 1892)?. Bull. Mens. O.N.C. 116:30-37.
Lescourret, F., and L. Ellison. 1987. Aires de distribution et éléments sur l'habitat des populations naturelles de Perdrix grise (Perdix perdix L.) des montagnes francaises, p. 101-112. In: EGPN-SRETIE/ONC (ed.), Actes du Colloque Galliformes de Montagne, Grenoble, France.

Magnani, Y. 1988. Sélection de l'habitat de reproduction et influence de l'évolution des pratiques sylvo-pastorales sur la population des TétrasLyre (Tetrao tetrix L.) de la réserve des Frètes (Haute-Savoie). Gibier Faune Sauvage 5:289-307.

Marcum, C.L., and D.O. Loftsgaarden. 1980. A nonmapping technique for studying habitat preferences. J. Wildl. Manage. 44:963-968.

Neu, C.W., C.R. Byers, and J.M. Peek. 1974. A technique for analysis of utilization-availability data. J. Wildl. Manage. 38:541-545.

Novoa, C., and G. Gonzalez. 1988. Comparaison des biotopes sélectionnés par le lagopède alpin (Lagopus mutus) et la perdrix grise (Perdix perdix hispaniensis) sur le Massif du Carlit (Pyrénées-Orientales). Gibier Faune Sauvage 5:187-202.

Office National de la Chasse (ONC). 1986. La Perdrix rouge. Tech. note, Bull Mens. 106: card 39.

Pialot, D., D. Chessel, and Y. Auda. 1984. Description de milieu et analyse factorielle des correspondances multiples. Comptes Rendus Acad. Sci. 298:309-314.

Prodon, R., J.D. Lebreton. 1981. Breeding avifauna of a Mediterranean succession: the holm oak and corn oak series in the eastern Pyrenees. I. Analysis and modelling of the structure gradient. Oikos 37:21-38.

Rotenberry, J.T., and J.A. Wiens. 1981. A synthetic approach to principal component analysis of bird/habitat relationships, p. 197-208. In: D. Capen (ed.), The use of multivariate statistics in studies of wildlife habitat. USDA, Forest Serv. Gen. Tech. Rep. RM 87.

Shugart, H.H. Jr., 1981. An overview of multivariate methods and their applications to studies of Wildlife Habitat, p. 4-10. In: D. Capen (ed.), The use of multivariate statistics in studies of wildlife habitat. USDA, Forest Service Gen. Tech. Rep. RM 87.

Ward, J.H. 1963. Hierarchical grouping to optimize an objective function. J. Amer. Stat. Assoc. 58:236-244. 